\title{
LAS VEGAS IS A FAITHFUL MORMON CITY: PHYLLIS BARBER'S SEARCH FOR IDENTITY THROUGH FICTION AND PLACE ${ }^{2}$
}

\author{
Angel Chaparro, Universidad del País Vasco \\ Email: saitxapa@hotmail.com
}

\begin{abstract}
In Phyllis Barber's memoir How I Got Cultured: A Nevada Memoir, Las Vegas exercises a pivotal role. The Mormon ideals of purity, modesty and chastity do not come to mind when thinking of Las Vegas. Barber's literature is a literary search for identity, and identity that allows good and evil in a wide array of possibilities. Las Vegas is in that sense the perfect stage to perform her search. Furthermore, Barber's autobiography contributes with a new different approach to Las Vegas as an iconic city and to the West as a paradigm in which American identity was formed.

Keywords: Barber, Phyllis - Mormon Literature and History - Western American Literature and History - Identity

Título en español: Las Vegas es una ciudad mormona con fe. La búsqueda de identidad de Phyllis Barber a través de la Ficción y el Lugar

Resumen: En How I Got Cultured: A Nevada Memoir, Phyllis Barber utiliza Las Vegas como un complejo escenario donde los valores fomentados por la cultura Mormona chocan con aquellos de la cultura popular y secular. Barber, cuya literatura se caracteriza por ser un instrumento de confección de su identidad individual, abraza la paradoja como elemento enriquecedor de esa construcción. Al mismo tiempo, las conclusiones que se extraen del análisis de su obra son aplicables, en un enfoque más general, al papel de la cultura Mormona dentro del marco de la historia y la literatura del Oeste de los Estados Unidos.

Palabras clave: Barber, Phyllis - Literatura e Historia Mormona - Literatura e Historia del Oeste de los Estados Unidos - Identidad
\end{abstract}

Phyllis Barber was born in present day Henderson, Nevada. When she was still a little girl, her family moved to Las Vegas. There she learnt to play the piano. She had learnt to love God before, back in Boulder City. Then she grew up. And she moved again. She learnt to write. She had learnt to love words before, when she was still a little girl hiding beneath a tablecloth. But this is just an elaborated, pretentiously pseudo-poetic way of making up an easy biography that fails to give any meaningful answer to the many questions that usually force writers to get involved into the adventure of defining themselves through the act of

Date of reception: 31 May 2010

Date of acceptance: 15 September 2010

2 The research for this article was carried out within the framework of the project MEC FFI 2008-03833/FILO and was also funded by the FEDER program. 
writing. Because Barber is a writer who approaches fiction with a good bunch of questions which she needs to answer, resolve, even if they remain unanswered, unresolved by the time the reader turns over the last page. In that context, Barber plays with her biases, with the elements that essentially encompass her definition of self to analyze them, complicate them, dismantle them. Inasmuch as our personal definitions are subjected by a powerful discourse of cultural and social factors, Barber dives into her own personal experiences to try to discover who she really is and how she really came to be who she is.

In Barber, one bias is that of land, but another one is that of time, time when, through experiences, becomes history, and, then, it can be distilled into stories, time again. Fluid. And Barber's search for identity is complex because it flows, it spreads both in time and in space. Las Vegas, the main landscape in her autobiography How I Got Cultured: A Nevada Memoir, is only one episode both in her own personal life, and in her writing career. In this article, I aim at analyzing, complicating, dismantling Barber's own recollection of the city so as to stem from her biased and personal search for identity general conclusions which could be applicable to the culture in which Barber's fiction inserts. In other words, Barber's singular observation of such an iconic city as Las Vegas not only discovers a personal exercise of literary introspection and search but it also derives into conclusive assumptions about the role and experience of the Mormons within the context of Western American Literature and History.

American geographer D. W. Meinig appreciates two different ways of understanding landscape. The difference is only directional, but it helps to illustrate how landscape plays an important role in defining or mapping our personal geographies of self. One way of understanding landscape is the following:

We may certainly agree that we will see many of the same elements - houses, roads, trees, hills - in terms of such denotations as number, form, dimension, and color, but such facts take on meaning only through association; they must be fitted together according to some coherent body of ideas. Thus we confront the central problem: any landscape is composed not only of what lies before our eyes but what lies within our heads. (MeINIG 1979: 1)

Nevertheless, D. W. Meinig also understands that there is a second way, a second direction which, rather than conflicting with the previous one, happens to be complementary to it. The first reflects how individuals perceive landscape and the second how landscape determines, shapes, formulates our personal definitions of self:

Carried further, one may discover an implicit ideology that the individuality of places is a fundamental characteristic of subtle and immense importance of life on earth, that all human events take place, all problems are anchored in place, and ultimately can only be understood in such terms. Such a view insists that our individual lives are necessarily affected in myriad ways by the particular localities in which we live, that it is simply inconceivable that anyone could be the same person in a different place. (MeINIG 1979: 8)

American author Julene Blair agrees with Meinig in giving that relevance to landscape, even when considering it from a literary point of view: "setting supersedes character" and 
helps thus to understand who we are. (BoARdman 2004: 49) Or, as Gary Snyder explains in a much more poetic way: "The trees we climb and the ground we walk on have given us five fingers and toes." (SNYDER 2000: 29) All these quotations prove helpful to introduce how Barber herself relies on place in her search for truth and definition through her own memory and experiences:

But finding her own way and carving out a new niche is a huge challenge, as it is for anyone belonging to a tribe, a family, or even at large, extended family. One's first home, after all, is the place where roots are nourished. It contains the emotional geography of childhood. (BARBER 2009: 200-201)

These statements operate as an introductory frame to understand the character of Barber's literary production. In fact, the following questions further illustrate the idea that place is an important element to achieve a proper rendition of her identity, specifically when this is approached from a literary perspective which inexcapably leans over the substance of time and memory:

In a sense, I'm still trying to find that life, having been derailed by the confusion of adolescence and later by the obligations of adulthood, but I need clues from the past as I move on. What was the milieu surrounding me as a child: the suppositions, the beliefs, the attitudes? Who were those people: my relatives, the rangers, the teachers in my church? And finally, need I always be a product of southern Nevada and the Mormon church? Made in the U.S.A. and Nevada by the Mormons? Am I a flower that can bloom anywhere, or will my roots shrivel in strange soil? (BARBER 1994: 10)

These questions are found in the introduction to her autobiography How I Got Cultured: A Nevada Memoir in which Barber offers a chronicle of her growing up as a Mormon in the city of Las Vegas. In How I Got Cultured: A Nevada Memoir, the city of Las Vegas plays an important role in both those ways which I confered from Meinig's quotations. The city and how the city participates on her construction of self are the fundamental perspectives of the book, but also, from a much more general point of view, this book helps to understand how Mormons fit in the context of Western American culture, history and literature. And this is the point of departure of my analysis.

The Church of Jesus Christ of Latter-day Saints was born in the $19^{\text {th }}$ century, not only a burgeoning period of religious blossoming, but also a period in which American identity was being discussed and elaborated: "Mormonism burst upon the scene at the time when the struggle for American independence was still a vivid memory of many" (GIVENS 1997: 151). In that context, Mormonism was "perceived as representing values and practices antithetical to the evolving images of America." (GIVEns 1997: 151)³. Constructing an identity by

\footnotetext{
3 Through his analysis of anti-Mormon literature from the $19^{\text {th }}$ century, Givens comes to the conclusion that Mormon development into an ethnic category was fabricated with the help of outsider forces rather than by their own concept of themselves as a peculiar people. (Givens 1997: 18). This idea was also employed by William Handley when he analyzed Zane Grey's Riders of the Purple Sage to conclude that the Mormons “were an important transitional group against which the nation defined itself based on marital practice and the question of consent." (HandLey 2002: 4) But Handley distances from Givens when he points out that it is not all a matter
} 
contrasting other is not an American invention, if ethnicity is not essential but invented, as Sollors proposes, but not a "conspirational interpretation of manipulative inventor" but some "intensely debated, collective fictions that are continually reinvented" (Sollors 1989: xi), Mormon played at the time American identity was being assembled, the role of the villain that faces the hero in the "collective fiction" being debated. And as White explained, the selection of Mormons for that role was a paradox in itself:

that Mormons should be tainted with the brush of un-Americanism is particularly ironic because Mormonism is in many ways the most American of religions. Founded in the United States by a New Englander, it incorporated many of the popular beliefs, religious controversies, and social values of early-nineteenth century rural New York in its theology. Nonetheless, persecution in Missouri and Illinois did in many ways mold the early Mormon church into an institution designed to survive in a world of enemies." (White 1991: 163)

Thus Mormons have been experiencing a complex process of identity challenge and ethnic derivative simplification that took them from being part of the margins ${ }^{4}$ to the fact that, today, the Mormon community is described "as the embodiment of public spiritedness and "traditional values"” (GIVENS 1997: 163). As Stegner says, Mormons were really "un-American" (STEGNER 1998: 104) when they pioneered the West with a set of values that counteracted the stereotypical image of the Western pioneering: "in place of nationalism, democracy, and individualism I suppose you'd have to put sectionalism, theocracy, and community." (STEGNER 1998: 104). Nevertheless, Stegner himself, agreeing thus with Givens, states that Mormons today are at the end of a process of integration based on an uneven combination of specialty and assimilation: "Nowadays I suppose you'd find as many patriots among Utah youth as you do among southern youth.” (STEGNER 1998: 104)

Mormonism began in the East but became in the West. Mormon's experience of the West displays a new array of approaches and perspectives and provides unique approach to American history but it also complicates it denoting a sense of belonging and estrangement that draws a complex paradox. In that sense, Mormon experience of the West asserts White's idea of the West as a complex space, full of paradoxes, different dimensions and perspectives. Mormons crossed the plains, opened the way to migrants behind, and set in motion a system of proselytizing that took new migrants from such places as Sweden or Norway, helping to compose the multicultural brew that today enriches American identity. They opened a way to a complex and dynamic understanding of a reality, that of the West, which has been subjected to multiple interpretations.

The history of the Mormons in relation to the West began when they were forced to leave Nauvoo in February 1846. The new leaders of the Church defended the exodus to the West not as something provoked by antagonistic opposition but rather as the fate of the

of dealing with "anxieties over religious heresy" but also "the contradictions of American religious intolerance, civil beliefs, and cultural practices." (HANDLEy 2002: 115)

4 As "racially different from the white majority, even when, in the case of the Mormons, they were white" (Handley 3) because of polygamy and some other issues that, as scholars like Leonard Arrington proposes, led to federal aggressive tactics against the Mormons in the $19^{\text {th }}$ century. 
Mormons. From 1840 to 1860 approximately 30,000 people travelled to the Far West on the overland trails. In February 1846 after detailed planning and conscientious organization the exodus began. Under the leadership of Brigham Young more than one hundred Mormons with seventy two wagons headed West. Their movement was communal rather than individual. On April 5, 1847, the first group of pioneers led by Young departed from Winter Quarters. The last stage of the exodus took 3 more months. By mid July scouts found the valley. On July 24 Young led 148 Mormons into the Valley. A few days later he proclaimed that that was the right place to establish the kingdom.

In any case, Young did not stop here and he promoted the settling of different areas out of Utah and the importance of the Mormons in neighbouring states such as Nevada, Idaho or Arizona was remarkable. John Wesley Powell, exploring the West in late $19^{\text {th }}$ century, left record of the help he got from Mormons' endevours. Robert Laxalt, in her history of Nevada, also chronicles the relevance of the Mormons in founding and forming the state. Especially, Laxalt talks about the Mormons when focusing on one of the most important cities in the territory, the city of Las Vegas ${ }^{5}$.

Originally founded in 1905 after a land auction by the Union Pacific Railroad, Las Vegas was in the beginning an unfruitful land surrounded by gold and silver mines. To come from a railroad stop to the luxurious gambling and resort center that it is today, Las Vegas underwent a vertiginous process, and Mormons always played an important role in this process. From the first adventurers sent by Young to the two mysterious, quasi-legendary assistants to Howard Hughes, Mormons always tried to settle the desert. In Inside Las Vegas, and with his own style, Mario Puzo makes a succinct account of the history of the city in which the presence of Mormons is obvious:

After we stole it from the Mexicans who had chased out the Spanish, Las Vegas was mostly inhabited by naked Paiutes addicted to long hours of rolling bones and coloured sticks across the sun and putting up their wives and horses to back their judgement. (Could it be that the special climate and earth themselves nurture the gambling instinct in man?) Anyway in 1855 Brigham Young sent some of his best strong-arm boys from Salt Lake City, Utah, to Las Vegas to convert the Indians and make the area an agricultural wonder.

The Mormons at that time and in that place had a reputation for having green thumbs and bloody red trigger fingers but even they were no match for the hot sun and the gambling fever of the natives. After three years, the Mormons gave up and went back to Salt Lake City. It turns out they made a mistake, because beneath that hot sand was untold wealth in gold and silver.

But in 1955, nearly a hundred years later, another Mormon, a young banker named E. Parry Thomas, left Salt Lake City and settled in Vegas. Whereas Brigham Young's green thumb and long rifles had failed to turn the desert oasis into anything worth while, E. Parry Thomas worked his financial black magic to transform the little town into a legendary metropolis that fascinates gamblers the world over. (Puzo 1977: 28)

Puzo even considers the irony of being a Mormon the one responsible for the blossoming of present day Las Vegas: "and it's sort of nice to know that Vegas came into full

\footnotetext{
5 In Nevada: A History, Laxalt traces a detailed summary of Las Vegas history in which the influence of the Mormons in the founding and building of the city is obvious.
} 
bloom because of a Mormon, finally." (Puzo 1977: 30) Puzo's perspective is that of an outsider who relies on a one-sided picture of Las Vegas. A bright picture which blinds the complexity of a place which hides a much more intricate nature. In fact, his ironic statement about the Mormon origin of the city echoes the profoundity of the gap he is leaving while approaching the city from a partial perspective.

Puzo's outsider perspective fits into Cheryll Glotfelty's theory of "bashing" which she develops in "Literary Place Bashing, Test Site Nevada." In that article, Glotfelty reviews the literary production about Nevada to ascertain that historically the state has been manipulated by magnifying negative aspects. Glotfelty underlines how, after Second World War, there is a change from wild landscapes to urban settings. In what she calls, "a double jeopardy" (Glotfelty 2001: 239), Glotfelty explains how the attention of the bashers moved from the desert to Nevada's cities, and especially to Las Vegas, the epitome of Nevada's urban development. Puzo's depiction of Las Vegas fits into this analysis. Promoting that face of Las Vegas as a suitable place for gambling, boozing and wild women, it seems that there is no margin for a normal, conventional, non-glamorous life. Puzo even observes the temporary nature of the city when he states that "though I once established a residence there I have rarely been able to stay more than three or four days." (Puzo 1977: 24) Las Vegas is thus an example of postmodern placelessness. In this multicultural, hybrid, and shifting identity of present-day Las Vegas, the city becomes a place of paradox. Tom Wolfe, Hunter S. Thompson, John O'Brien or Puzo's experiences of Las Vegas describe the city as a valuable artefact to denote certain mental state or attitude. Las Vegas is rather an artificial device, "a religion, a disease, a nightmare, a paradise for the misbegotten." (TRONNES 1995: $\mathrm{xv}$ ) The city seems to respond to the writer's necessity to find a fitting setting to illustrate their character's redeeming or self-destructive catharses.

However, Las Vegas becomes a convoluted stage when Mormonism appears on scene. Through the analysis of Barber's rendition of the city, Las Vegas functions as a trigger for Barber's main character's psychological development as well, but, this time, by presenting a new contrast to the commonly pictured image of the city. Barber helps to show a more intricate and ambiguous interpretation of it, especially when that glamorous and visible environment clashes with the growing up as a Mormon of a young sensitive girl who longs for new experiences. Las Vegas, in Barber's fiction, is a complex place. A place of paradox, a ground in which that glamorous side of the city comes across the backstage of such a cinematic scenario. For a Mormon girl like her, being raised in Las Vegas, becomes a challenge, even a troublesome experience:

Maybe growing up Mormon in Las Vegas has a way of making one into an oyster, one whose soft lining gets irritated by paradox until a strange pearl is formed. One can't refuse to see the wider world growing up in that windblown city. It's sensurrounded in the Nude. (BARBER 1990: 191)

Her coming-of-age is framed between two different lifestyles or cultures available for her: that of the popular culture and glamour of Las Vegas and the one promoted by the Mormon Church. Barber's moral decision leads her to turn round and look right into the eyes of the snake, because Barber relies on that stereotypical image of Las Vegas to unfold 
the overstated elements of the archetypal representation. Through her heterogeneous rendition of the city, Barber accomplishes a complete image that presents a wholesome, complex perception of Las Vegas. In this zone of tension, Fremont Street plays an important role. It is just a straight line in the desert where people go to try their luck but she prefers a different way: "I'd have to get what I wanted in some other way, maybe from God if I kept saying my prayers every night before bedtime." (BARBER 1994: 169) She learns that the glitter and the bright lights are not the real thing by going behind the spontaneous emotion:

But I'd been behind these buildings; I knew they were made of regular things like bricks, glass, stone, and clay, even though they were camouflaged by the lights and their storehouses of games, diversions, machines that seemed to manufacture money, tables where lucky became rich, rich, rich when their hands curled around a stack of chips. (BARBER 1994: 176)

That is the symbolic triumph over the challenge that Las Vegas meant for her. The vibrant triumph over her identity and her coming-of-age. Now she is able to leave: "I'll be at Brigham Young University where I can escape this place, this phony city, this Las Vegas of the mind --- desert, heat, gambling, no sense of higher values." (BARBER 1994: 180) The challenge resided in surviving her Mormon training in a place like this. She was open to experience it, to face it, and she did. Las Vegas was a kind of handicap that she had to overcome to get to know herself and build her identity, as she has to do with Mormonism and gender roles.

It seems a constant in literature that Las Vegas is characterized as a "double place", as a space with two faces, virtually independent, and only one of them seems to be worthy of literary appreciation. Nevertheless, the shadow of the first, more visible Las Vegas, the Las Vegas of the lights and glittering is always present in Barber's fiction as powerfully as the one she uses to place her stories, that of humble households, school playgrounds and Mormon wards. In fact, Barber approaches Las Vegas with a conscious understanding of this dual character. In that border, Barber deliberately establishes a zone of tension in which both sides clash and unveil the manipulation granted by any superficial interpretation. That differentiation contributes to read this clash between both sides as an effective analogy of the same clash that Mormons happen to experience when they have to place their peculiar culture among a secular world which opens them to a whole range of possibilities. From their cultural environment to the possibilities embedded in a secular world, there is a gap enlarged by the conspicuous and overwhelming archetype provided by Las Vegas, where the extremes seem so palpable and accessible: "I lived in Boulder City until I was 12 , before my family moved twenty-five miles away to another planet called Las Vegas" (BARBER 1994: x).

In "Beyond the Glitter", an article that Janet Brigham wrote in 1979 for the official Church's magazine, Ensign, in order to report about the work that faithful Mormons were doing in Las Vegas, she reproduces that notion that Las Vegas is a bipolar city:

Las Vegas, the gambling capital of the United States, is renowned for its casinos and shows, its pornography and prostitution. That side of Las Vegas exists, but not in the lives 
of an overwhelming number of Church members there; they live in another world, one filled with opportunities for spiritual growth (BRIGHAM 1979: 36)

Las Vegas, thus, is seen by Mormons themselves as a challenge that means rather than facing, avoiding; a temptation which they must confront. In fact, as some of the persons that Brigham interviews confess, this situation is understood as a given: President Tanner insists "there are places in the city where you just don't go." And he adds: "The kids have to be strong." (BRigham 1979: 38) President Simmons, when asked about the Strip, shows concern about the adolescent members: "They learn in their homes what it is. We don't have to consciously counteract the bad influence." (BRIGHAM 1979: 38) And finally Brother Hayes' words close the article with a conclusive statement: "Las Vegas is a crucible as far as making moral decisions." (BRIGHAM 1979: 39)

In Barber's memoir, Las Vegas is essentially a character with a pivotal role. The Mormon ideals of purity, modesty and chastity do not come to mind when thinking of Las Vegas. This new environment offered the young Phyllis experiences that enabled the seed of doubt that was disrupting her faith to develop. In fact, this is just reflecting her overall growth both socially and culturally. Barber's literature is a literary search for identity: "you want to use your gift of imagination. You hope it's possible to lift your experience from its limited boundaries and transform it into a unique bloom of perception." (BARBER 2009: xxii). Barber's identity is composed of different elements and some of them incorporate tensions and conflicts that are heightened by Barber's own conscious awareness of that complex balance. Joanna Brooks perfectly defined Mormon identity as "historically contingent, highly contested, and perpetually tenuous construct." (BROOKS 2003: 293) Barber pulses the tension between moving and remaining, between migration and belonging, between a secure household and an uncertain adventure. Barber own's definition of identity as a matter of biases allows contradiction, complexity, conflict and unattainability, a definition that allows her to portray good and evil in the wide array of possibilities that this complex dichotomy may produce, and Las Vegas is in that sense the perfect stage to perform this struggle. In that zone of tension provided by Las Vegas, Barber establishes the place to define herself through the different aspects of an identity which is beginning to blossom: music, faith, culture, experience. She does not reject, but embraces the paradox, the challenge, the clash to try to find a balance that may be impossible but worth taking. Thus she confronts her doubts, she faces her desires and the possible consequences. She learns to play the piano, models, becomes a Rhythmette, but always within her community, trying to balance the compulsion to know and to sense risk with the inevitable urgency to belong, her necessity of a family and a community.

Barber's autobiography contributes with a new different approach to Las Vegas as an iconic city and to the West as a paradigm in which American identity was formed. A different approach in which the Mormons and their sometimes underestimate influence help to complicate the culture and nature of a place which needs to state its complexity in order to disassemble the discourse which has been elaborating a mythic, artificial, archetypal definition of it. In the Las Vegas of the 1950s, when Frank Sinatra was having dinner with Lauren Bacall, or in the Western land where Daniel Boone was conquering the horizon, the Mormons played a role which opens a complex perspective, a complex perspective 
for non-Mormons, who need to recalculate the new set of values encouraged by this community, and for Mormons themselves who, as Barber describes in her autobiography, have an enriching complexity to embrace in the approximately 1,500 feet of a street that seems to be paved with challenge.

\section{REFERENCES}

BArber, P. 1994. How I Got Cultured: A Nevada Memoir. Reno: University of Nevada Press.

1999. “CAUTION: Men in Trees" Dialogue: A Journal of Mormon Thought 32 (4) Winter: 189-192

2009. “Big Love Before Big Love: Dorothy Allred Solomon's In My Father's House: A Memoir of Polygamy”. Irreantum Vol II, no. 1 \& 2 (2009): 199-203

. 2009. "Writing: An Act of Responsibility" The Best of Mormonism. S. CARTER. Salt Lake City: Curelom Books. xiii-xxi

BoARdman, K. A. ANd G. Woods, ED. 2004. Western Subjects: Autobiographical Writing in the North American West. Salt Lake City: The University of Utah Press.

Brigham, J. 1979. "Beyond the Glitter” in Ensign, Feb 1979: 36-41

Brooks, J. 2003. "'Genealogy is In Our Blood': Terry Tempest Williams and the Redemption of "Native" Mormonism." True West: Authenticity and the American West. W. H. HANDLEY and N. LEWIS. Lincoln: University of Nebraska Press. 290-303

Givens, T. L. 1997. The Viper on the Earth: Mormons, Myths, and the Construction of Heresy (Religion in America). New York: Oxford University Press.

Glotfelty, C. 2001. "Literary Place Bashing, Test Site Nevada." Beyond Nature Writing: Expanding the Boundaries of Ecocriticism. Eds. K. ARMBRUSTER and K. R. WALLACE. Charlottesville, Virginia: University of Virginia Press. 233-247

Handley, W. R. 2002. Marriage, Violence, and the Nation in the American Literary West. Cambridge: Cambridge University Press.

Laxalt, R. 1991. Nevada: A History. Reno: University of Nevada Press.

MeInig, D. W. 1979. “The Beholding Eye: Ten Versions of the Same Scene.” The Interpretation of Ordinary Landscapes. Ed. D. W. MEINIG. Oxford: Oxford University Press. 33-48

Puzo, M. 1977. Inside Las Vegas. Grosset \& Dunlap: New York.

Snyder, G. 2000. The Practice of the Wild. New York: North Point Press.

Sollors, W., ED. 1989. The Invention of Ethnicity. New York: Oxford University Press.

Stegner, W. and R. W. Etulain. 1998. Stegner: Conversations on History and Literature. Reno: University of Nevada Press. 
Tronnes, M., ED. 1995. Literary Las Vegas: The Best Writing About America's Most Fabulous City. New York: Henry Holt and Company.

White, R. 1991. "It's Your Misfortune and None of My Own:" A New History of the American West. Norman: University of Oklahoma Press. 